\title{
KAJIAN PENGELOLAAN USAHATANI KELAPA DI DESA TOLOMBUKAN KECAMATAN PASAN KABUPATEN MINAHASA TENGGARA
}

\author{
Eyverson Ruauw \\ Jenny Baroleh \\ Devison Powa
}

\begin{abstract}
This study aims to assess the management of coconut farms in village of Tolombukan district of Pasan mainly include land area, production, revenue, and marketing. The results could be input materials and information for farmers in increasing production and income of coconut farmers in of Tolombukan district Pasan.

The research was carried on in the of Tolombukan district of Pasan which lasted from June 2010 until August 2010. Data taken in this study are primary data that was obtained through interviews to farmers based on a list of questions and secondary data obtained from agencies - agencies. Sampling method used in this study is simple random sampling method with a sample size of 20 farmer respondents. Data is presented in tables and is explained descriptively. The data are mainly in the form of costs, income, and revenue.

Results showed that coconut farmers harvest pass once in 3 months so that in one year there are 4 times the harvest with an average area of 1.59 ha. The other results of thisr studies are outlined below. The results of the average oil production in the village of Tolombukan district of Pasan of $2375.9 \mathrm{~kg}$ of copra per year with an average income of Rp4.891.948, 78 per year. In addition to plant coconut, farmers also planted cloves between the coconut that provide an income of Rp11.734.695, 84 per two years or Rp5.867.000 per year. The product of copra and cloves sold at traders in the village Tolombukan own.
\end{abstract}

Keywords: Management, Coconut Farm.

\section{PENDAHULUAN}

\section{Latar Belakang}

Kelapa (Cocos nucifera.L) merupakan tanaman jenis palma yang mempunyai nilai ekonomis cukup tinggi dalam dunia perdagangan, di Indonesia merupakan Negara penghasil kelapa terbesar yang utama di dunia. Menurut Sukamto (2001), kelapa di Indonesia bersaing dengan kelapa sawit. Produk- produk unggulan kelapa antara lain minuman segar dari kelapa, santan kelapa, kelapa parut kering, gula kelapa dan kue kelapa. Selain itu produk- produk kelapa banyak di gunakan pada industri-industri non pangan antara lain, industri sabut kelapa, arang aktif, aleokimia bahkan kerajinan tangan.

Pada tahun 2007 luas areal tanaman kelapa di Indonesia tercatat 3.860 ribu ha, didominasi oleh perkebunan rakyat seluas 3.791 ribu ha $(98,21 \%)$, perkebunan besar negara seluas 6 ribu ha $(0,15 \%)$ dan perkebunan swasta seluas 63 ribu ha $(1,63 \%)$, dengan total produksi sebesar 3.039 ribu ton setara kopra, yaitu perkebunan rakyat sebesar 2.967 ribu ton $(97,63 \%)$, perkebunan besar negara sebesar 5,1 ribu ton $(0,17 \%)$ dan perkebunan besar swasta sebesar 67,26 ribu ton $(2,21 \%$ ) (Anonymous 2008).

Di Sulawesi Utara kelapa merupakan sumber pendapatan yang sangat penting. pada umumnya penduduk Sulawesi Utara hidup dari sektor pertanian, dimana sebagian besar masyarakat Sulawesi Utara adalah petani. sehingga di harapkan kesejahteraan petani sebagian besar berasal dari usahatani kelapa.

Dalam sektor pertanian kelapa merupakan komoditas tradisional yang secara komersial dapat di hasilkan dalam bentuk kopra, minyak kelapa, makanan segar dan lain-lain. Indonesia kurang 
lebih 3 juta ha tanah yang di tanami kelapa yang terdiri dari 55 persen di tanam secara monokultur (tunggal) dan 45 persen di tanam dengan campuran tanaman lain (Darwis, 1986).

Masalah harga yang cenderung berubah- ubah dari waktu ke waktu merupakan salah satu faktor yang di hadapi petani kelapa sekarang. Perkembangan harga kopra di Sulawesi Utara dari tahun 2003 samapai dengan 2009 dapat di lihat pada Tabel 1.

Tabel 1.Perkembangan Harga Rata - Rata Kopra di Sulawesi Utara

\begin{tabular}{|c|c|}
\hline Tahun & $\begin{array}{c}\text { Harga } \\
(\mathrm{Rp} / \mathrm{kg})\end{array}$ \\
\hline 2003 & 2.100 \\
2004 & 3.000 \\
2005 & 2.875 \\
2006 & 2.825 \\
2007 & 4.241 \\
2008 & 5.881 \\
2009 & 3.506 \\
\hline
\end{tabular}

Sumber: Dinas Peindustrian dan Perdagangan Sulawesi Utara, 2010

Tabel 1 di atas menunjukan bahwa kecenderungan naik - turunnya harga kopra dari tahun ke tahun. Masalah harga kopra yang cenderung naik turun ini, membuat para petani kurang memperhatikan mengenai perkembangan dan pertumbuhan tanaman kelapa. Hal ini mempengaruhi pendapatan petani. Sesuai dengan yang di jelaskan Mosher (1991) bahwa setiap petani akan berusaha mengembangkan usaha taninya apabila ada jaminan harga terhadap produksinya. Jika harga menguntungkan maka petani akan berusaha lebih banyak lagi, sehingga harga dalam hal ini merupakan bimbingan bagi petani dalam menentukan jumlah yang akan di produksinya.

Desa Tolombukan Kecamatan Pasan dalam perkembangan dunia usahataninya lebih menonjol pada usahatani kelapa dari pada tanaman perkebunan lainnya seperti: cengkih, kopi, vannili, dan coklat. Pada umumnya tanaman kelapa di budidayakan oleh seluruh desa yang ada di Kecamatan Ratahan dan semuanya itu sebagian besar di olah menjadi kopra di samping di konsumsi dalam bentuk buah segar, baik untuk kebutuhan rumah tangga dan industri.

Berikut ini adalah gambaran mengenai jumlah lahan dan produksi kelapa (kopra) di Desa Tolombukan Kecamatan Pasan dari tahun 2005 sampai dengan 2009.

Tabel 2. Luas Areal, Jumlah Produksi dan Produktivitas Kelapa di Desa Tolombukan Kecamatan Pasan

\begin{tabular}{|c|c|c|c|c|c|}
\hline \multirow[b]{2}{*}{ Tahun } & \multicolumn{3}{|c|}{ Klasifikasi Tanaman } & \multirow[b]{2}{*}{$\begin{array}{l}\text { Jumlah } \\
\text { (ha) }\end{array}$} & \multirow{2}{*}{$\begin{array}{c}\text { Produksi } \\
\text { kopra } \\
\text { (ton) }\end{array}$} \\
\hline & $\begin{array}{c}\text { TMBM } \\
\text { (ha) }\end{array}$ & $\begin{array}{l}\text { TM } \\
\text { (ha) }\end{array}$ & $\begin{array}{l}\text { TTM } \\
\text { (ha) }\end{array}$ & & \\
\hline 2005 & 11,50 & 155,60 & 9,35 & 176,45 & 166,72 \\
\hline 2006 & 14,75 & 157,68 & 9,50 & 181,93 & 189,21 \\
\hline 2007 & 16,65 & 159,50 & 10,75 & 186,90 & 191,40 \\
\hline 2008 & 17,85 & 160,85 & 12,75 & 191,45 & 193,02 \\
\hline 2009 & 18,50 & 160,95 & 12,80 & 192,25 & 193,14 \\
\hline
\end{tabular}

Sunber: Dinas Perkebunan Kecamatan Pasan 2010

Keterangan:

TBM : Tanaman Muda Belum Menghasilkan

TM : Tanaman Menghasilkan

TTM : Tanaman Tidak Menghasilkan

Dari Tabel 2 di atas menunjukan bahwa produksi kopra di Desa Tolombukan dari tahun ke tahun mengalami peningkatan, kacuali antara tahun 2008 dan tahun 2009 dengan nilai produksi sama 193 ton. Hal di sebabkan oleh perubahan musim, jadi rata - rata produksi kopra per ha adalah 1.2 ton.

\section{Perumusan Masalah}

Berdasarkan latar Belakang di atas, maka yang menjadi permasalahan dalam penelitian ini yaitu bagaimana pengelolaan usahatani kelapa di Desa Tolombukan Kecamatan Pasan.

\section{Tujuan dan Manfaat Penelitian}

Mengkaji pengelolaan usahatani kelapa di Desa Tolombukan Kecamatan Pasan yang meliputi pemilikan lahan, luas lahan, jarak perkebunan, jarak tanam, umur tanaman, produksi, biaya produksi, penerimaan dan pendapatan, pemasaran di tingkat petani. Adapun manfaat dari penelitian ini yaitu sebagai bahan masukkan dan bahan 
informasi bagi petani dalam perencanaan dan pengelolaan usahatani kelapa khususnya dalam peningkatan produksi dan pendapatan petani kelapa di Desa Tolombukan Kecamatan Pasan.

\section{TINJAUAN PUSTAKA}

\section{Deskripsi Tanaman Kelapa}

Seperti yang di jelaskan oleh Mahmud, (1998) bahwa kelapa termasuk genus cocos dengan nama spesis cocos nucifer L. Tanaman Kelapa memiliki akar serabut dengan bentuk batang yang keras memilki bunga yang tumbuh keluar dari ketiak daun. Selanjutnya di jelaskan secara ekonomis bahwa kelapa memiliki banyak manfaat bagi kehidupan manusia karena hampir semua bagian tanaman dapat di manfaatkan oleh manusia mulai dari daun, batang, bunga serta buah.

Tanaman kelapa menghendaki iklim panas dan dengan batas suhu udara tertentu untuk hidupnya.Suhu rata-rata tahunan untuk kehidupan optimal adalah $29^{\circ} \mathrm{C}$ dan untuk pertumbuhan buah memerlukan suhu rata-rata $25^{\circ} \mathrm{C}$ dengan kisaran antara $5^{0} \mathrm{C}-7^{0} \mathrm{C}$. Tanaman ini amat peka terhadap perubahan suhu yang amat menyolok,karena akan mengakibatkan rendahnya hasil dan pertumbuhan buah yang jelek.

Menurut Warisno (1998), ciri-ciri kelapa dalam, sebagai berikut:

a. Umur mulai berbuah relatif lebih lama yaitu sekitar 5-8 tahun setelah tanam.

b. Ketinggian batang dapat mencapai 25 meter atau lebih.

c. Umur produksi tanaman 50 tahun lebih.

d. Batang, daun, buahnya relatif lebih besar.

Tanaman kelapa termasuk tanaman yang membutuhkan sinar matahari yang banyak, lamanya penyinaran sangat berpengaruh atas perkembangan tanaman. Suatu laporan menyimpulkan bahwa batas minimum kebutuhan sinar yaitu 120 jam per bulan. Apabila lama penyinaran kurang dari batas tersebut akan dapat menggangu pertumbuhan sekaligus produksi tanaman.

Tanaman kelapa paling baik tumbuh di daerah yang memiliki ketinggian 0-500 $\mathrm{m}$ di atas permukaan laut. Biasanya perkebunan kelapa terletak di daerah antara 0-200 m, sedangkan kelapa rakyat kebanyakan terletak diantara 200$500 \mathrm{~m}$. Daerah yang terlampau tinggi letaknya akan mengakibatkan pertumbuhannya terlampau lambat dan buahnya kurang memuaskan.

\section{Konsep Usahatani}

Usahatani merupakan usaha yang di lakukan oleh petani untuk mendapatkan keuntungan dan kesejahteraan dari pertanian. Jadi usaha tani adalah sebagai organisasi dari alam yang di usahakan oleh petani, keluarga tani, lembaga atau badan usaha lainnya yang berhubungan dengan pertanian untuk memenuhi kebutuhan masyarakat.

Menurut Soekartawi (1995), usahatani adalah ilmu yang mempelajari bagaimana seseorang mengalokasikan sumberdaya yang ada secara efektif dan efisien dengan tujuan untuk memperoleh keuntungan yang tinggi pada waktu tertentu. Dikatakan efektif bila petani atau produsen dapat mengalokasikan sumberdaya yang mereka miliki atau yang dikuasai sebaik-baiknya dan dikatakan efisien bila pemanfaatan sumberdaya tersebut menghasilkan keluaran (output) yang melebihi masukan (input)

Ratag (1982) mengatakan bahwa ilmu usahatani merupakan ilmu yang mempelajari caracara menentukan serta mengkoordinasikan penggunaan faktor- faktor produksi seefektif mungkin sehingga produksi pertanian memberikan pendapatan keluarga petani yang lebih baik. Definisi ini terkandung satu tujuan utama yaitu peningkatan pendapatan keluarga petani.

Selanjutnya Adiwilaga (1982), menjelaskan bahwa ilmu usahatani adalah ilmu yang menyelidiki segala sesuatu yang berhubungan dengan segala kegiatan orang yang melakukan pertanian dan masalah ditinjau secara khusus dari kedudukan pengusahanya.

Menurut Hernanto (1993), yang menjadi unsur- unsur pokok usaha tani yang di kenal dengan faktor-faktor produksi, yaitu: tanah, tenaga kerja, modal dan manjemen.

\section{Konsep Tentang Biaya}

Menurut Djojodipuro (1991), biaya di definisikan sebagai pengeluaran dalam bentuk proses produksi tidak dapat di hindarkan, hal ini 
berarti proses produksi harus di jalankan secara efisien dengan menghindari pemborosan, sedangkan menurut Soekartawi (1995), biaya adalah semua pengeluaran yang di pergunakan oleh petani dalam suatu usaha.

Soekartawi (1995), mengemukakan bahwa biaya adalah semua pengeluaran yang di gunakan dalam suatu usaha yang meliputih: biaya tetap (fixed cost) dan biaya variabel (variable cost).

Menurut Bishop dan Toussaint (1979), dalam menghasilkan produk akan menunjuk pada biaya yang di keluarkan, dalam menghasilkan suatu jumlah hasil produksi pada suatu periode waktu tertentu. Biaya produksi terbagi atas biaya tetap dan biaya variabel, biaya tetap di tambah biaya variabel sama dengan biaya total. Biaya total pemting dalam memperhitungkan pendapatan bersih sama dengan penerimaan total di kurangi biaya total.

\section{Konsep Penerimaan dan Pendapatan Usahatani Penerimaan Usahatani}

Menurut Hernanto (1993), penerimaan usahatani yaitu penerimaan semua sumber usahatani meliputi nilai jual beli, penambahan jumlah inventaris, nilai produk yang di konsumsi petani dan keluarganya. Sedangkan Soekartawi (1995), penerimaan usahatani adalah perkalian antara produksi yang di peroleh dengan harga jual.

\section{Pendapatan usahatani}

Mubyarto (1991), menjelaskan bahwa pendapatan adalah hasil pengurangan antara hasil penjualan dengan semua biaya yang di keluarkan mulai dari produksi sampai pada produk tersebut berada pada tangan konsumen. Pada dasarnya petani dalam meningkatkan produksi adalah untuk meningkatkan pendapatan yang akan di terimanya. Hasil produksi yang di hasilkan dari setiap jenis usahatani akan di nilai dari biaya yang akan di keluarkan dan penerimaan yang di peroleh. Selisih keduanya merupakan pendapatan petani (Kartosapoetra, 1991)

Soekartawi, dkk (1986) mengemukakan parameter pendapatan usaha tani sebagai berikut:

1. Penerimaan usahatani

Penerimaan usahatani didefinisikan sebagai nilai dari total produksi suatu usahatani dalam jangka waktu tertentu baik yang di jual maupun tidak di jual.

2. Pengeluaran Usahatani

Pengeluaran total adalah nilai dari semua input yang habis terpakai dan di keluarkan dalam proses produksi tetapi tidak termasuk tenaga kerja dalam keluarga petani.

3. Pendapatan Usahatani

Pendapatan usahatani adalah selisih antara penerimaan dan pengeluaran total usahatani.

\section{METEDOLOGI PENELITIAN}

\section{Metode Pengumpulan Data}

Metode penelitian yang di gunakan yaitu metode survei di Desa Tolombukan Kecamatan Pasan Kabupaten Minahasa Tenggara, data yang di gunakan berupa data primer yang di peroleh menggunakan kusioner dan wawancara langsung berdasarkan daftar pertanyaan terhadap petani sampel.

\section{Metode Pengambilan Sampel}

Metode pengambilan sampel petani dilakukan secara Simple Random Sampling (pengambilan sampel secara acak sederhana) dengan jumlah sampel yang diambil 20 petani.

\section{Konsepsi Pengukuran Variabel}

Adapun variabel-variabel yang di amati dan di ukur dalam penelitian ini yaitu:

1. Pemilikan lahan:

- Status garapan

- Luas lahan usahatani Kelapa dinyatakan dalam hektar (ha)

2. Keadaan Usahatani Tanaman Kelapa

- Umur tanaman kelapa (tahun)

- Jumlah Pohon Kelapa dinyatakan dalam pohon

- Jarak Perkebunan dari desa penelitian (km)

3. Jumlah produksi kelapa butiran dan kopra yang di peroleh selama satu tahun, yang dinyatakan dalam jumlah buah dan kilogram

4. Harga jual yang berlaku di tingkat petani $(\mathrm{Rp} / \mathrm{kg})$. 
5. Penerimaan usahatani kelapa (produksi dikali harga jual) dalam satu tahun di nyatakan dalam rupiah (Rp).

6. Biaya produksi yaitu biaya yang di keluarkan petani dalam satu kali proses produksi (panen) dalam jangka satu tahun dalam usahatani kelapa, meliputi:

1. Biaya tetap

- Pajak, yang dinyatakan dalam rupiah per tahun (Rp/Tahun)

- Biaya penyusutan Alat (Rp), di hitung dengan menggunakan "Straight line method".

2. Biaya variabel

a. Biaya sarana produksi

- Pupuk (Rp/Kg)

- Pestisida (Rp/Botol)

b. Biaya tenaga kerja

- Pembersihan

- Pemupukan

- Penyemprotan

- Pemanjatan

- Pengumpulan

- Pengupasan

- Pembelahan

- Pengolahan

c. Pengangkutan

7. Pendapatan Usahatani kelapa yaitu selisih antara penerimaan dan pengeluaran.

8. Pengeluaran usahatani lain (tanaman sela) yaitu, seluruh biaya yang dikeluarkan selama proses produksi (Rp)

9. Penerimaan usahatani lain (tanaman sela) yaitu, perkalian antara produksi dengan harga jual (Rp)

10. Pendapatan usahatani lain yaitu, pendapatan usahatani diluar usahatani kelapa (tanaman sela), diperoleh dari selisih antara penerimaan dengan pengeluaran $(\mathrm{Rp})$

11. Pemasaran di tingkat petani usahatani kelapa dan di luar usahatani kelapa (tanaman sela)

12. Karakteristik petani

- Umur petani

- Tingkat pendidikan

- Tanggungan keluarga

\section{Analisis Data}

Data dalam penelitian ini di analisis secara deskriptif dan di sajikan dalam bentuk tabel, dan di lanjutkan dengan mengacu pada rumus perhitungan biaya, pendapatan, da $\mathrm{n}$ penerimaan. Untuk mengetahui besarnya biaya yang dikeluarkan, digunakan perhitungan:

Dimana:

$$
\mathrm{TC}=\mathrm{FC}+\mathrm{VC}
$$

$$
\begin{aligned}
& \mathrm{TC}=\text { Total Cost }(\text { Biaya Total }) \\
& \mathrm{FC}=\text { Fixed Cost (Biaya Tetap) } \\
& \text { VC }=\text { Variabel Cost (Biaya Variabel })
\end{aligned}
$$

Menurut Soekartawi (1995), pendapatan usaha tani adalah selisih antara jumlah penerimaan dan semua biaya.

Dimana:

$$
\mathrm{Pd}=\mathrm{TR}-\mathrm{TC}
$$

$$
\begin{aligned}
& \mathrm{Pd}=\text { Pendapatan Usaha Tani } \\
& \mathrm{TR}=\text { Total Penerimaan } \\
& \mathrm{TC}=\text { Total Biaya }
\end{aligned}
$$

Sedangkan untuk menghitung penerimaan usahatani adalah produksi yang di peroleh dengan harga jual.

$$
\mathrm{TR}=\mathrm{Q} \times \mathrm{Pq}
$$

Dimana:

TR = Total Revenue

$\mathrm{Q} \quad=$ Jumlah produksi yang di jual

$\mathrm{Pq}=$ Harga tiap satuan produksi

\section{Waktu dan Tempat Penelitian}

Penelitian ini berlangsung selama tiga bulan, mulai dari Persiapan hingga penyusunan laporan penelitian yaitu dari bulan juni 2010 sampai agustus 2010. Dengan lokasi penelitian di Desa Tolombukan Kecamatan Pasan Kabupaten Minahasa Tenggara. 


\section{HASIL PENELITIAN DAN PEMBAHASAN}

\section{Umur Petani}

\section{Karakteristik Petani}

Umur petani menentukan prestasi kerja yang dicapai oleh petani serta mempengaruhi kemampuan fisik bekerja dimana jika semakin tinggi umur seseorang setelah melewati batas umur tertentu maka makin berkurang kemampuan berprestasi sebagai tenaga kerja. Petani masih muda dan sehat mempunyai tenaga yang lebih besar dari pada petani yang sudah tua. dari hasil penelitian diperoleh umur petani responden berkisar $30-78$ tahun

Tabel 3. Jumlah dan Persentase Petani Responden Menurut Golongan Umur

\begin{tabular}{|c|c|c|}
\hline $\begin{array}{c}\text { Umur } \\
\text { (tahun) }\end{array}$ & $\begin{array}{c}\text { Jumlah Petani } \\
\text { Responden } \\
\text { (orang) }\end{array}$ & $\begin{array}{c}\text { Persentase } \\
(\%)\end{array}$ \\
\hline $30-40$ & 4 & 20 \\
\hline $41-50$ & 5 & 25 \\
\hline $51-60$ & 5 & 25 \\
\hline$\geq 61$ & 6 & 30 \\
\hline Jumlah & 20 & 100 \\
\hline
\end{tabular}

Tabel 3 menunjukan bahwa tingkat umur responden yang memiliki persentase terkecil pada kelompok umur 30 - 40 tahun yaitu sebesar 20 persen dari jumlah petani responden dan kelompok umur lebih dari 61 tahun memiliki persentase terbesar yaitu 30 persen.

\section{Tingkat Pendidikan}

Pendidikan merupakan kebutuhan pokok bagi setiap anggota masyarakat dalam peningkatan sumber daya manusia. Pendidikan mempengaruhi seseorang dalam menentukan sikap, peningkatan intelektual dan bahkan dalam hal pengambilan keputusan untuk mengelolah usahataninya. Tinggi rendahnya tingkat pendidikan petani responden dapat dilihat pada Tabel 4 .
Tabel 4. Jumlah dan Persentase Petani Responden Berdasarkan Tingkat Pendidikan

\begin{tabular}{|c|c|c|}
\hline $\begin{array}{c}\text { Tingkat } \\
\text { pendidikan }\end{array}$ & $\begin{array}{c}\text { Jumlah petani } \\
\text { (orang) }\end{array}$ & $\begin{array}{c}\text { Persentase } \\
(\mathbf{\%})\end{array}$ \\
\hline SD & 4 & 20 \\
\hline SMP & 8 & 40 \\
\hline SMA & 6 & 30 \\
\hline Perguruan Tinggi & 2 & 10 \\
\hline Jumlah & 20 & 100 \\
\hline
\end{tabular}

Sumber: Data Primer, 2010

Tabel 4 menunjukan bahwa tingkat pendidikan yang paling banyak tingkat pendidikannya adalah Sekolah Menengah Pertama (SMP) sebesar 40 persen dari jumlah petani responden. hal ini menunjukan walaupun pendidikan petani masih tergolong rendah tetapi mereka tetap mengelolah usahataninya ini dengan baik, kerena petani-petani ini sudah berpengalaman. Tingkat pendidikan yang terendah adalah perguruan tinggi (sarjana) sebesar 10 persen. Hal ini menunjukan bahwa petani responden telah mengecap pendidikan yang tinggi sehingga dalam mengelolah usahataninya sudah baik dan akan lebih cepat menerima teknologi - teknologi baru dalam usahataninya.

\section{Jumlah Tanggungan Keluarga}

Jumlah tanggungan keluarga mempengaruhi penghasilan dalam suatu usahatani. Jumlah anggota yang cukup besar menyebabkan kurang di perhatikannya pola konsumsi yang akan di terima oleh seseorang apabila penghasilannya dalam berusahatani kecil atau rendah. Namun disisi lain jumlah keluarga yang besar merupakan bantuan tenaga kerja yang dapat mengelolah usahatani. Jumlah tanggungan keluarga dapat di lihat pada Tabel 5. Tabel 5 menunjukan bahwa jumlah tanggungan keluarga petani responden yang paling terkecil 20 persen dari jumlah petani responden dan memiliki jumlah tanggungan yang terbesar yaitu 50 persen dari jumlah responden. Dengan adanya jumlah tanggungan petani responden yang memiliki tanggungan lebih dari 3 orang, maka dapat memperkecil penggunaan tenaga kerja dari luar keluarga dan sangat mempengaruhi kesejahteraan petani. 
Tabel 5. Jumlah dan Persentase Petani Responden Berdasarkan Tanggungan Keluarga

\begin{tabular}{|c|c|c|}
\hline $\begin{array}{c}\text { Jumlah } \\
\text { tanggungan } \\
\text { (orang) }\end{array}$ & $\begin{array}{c}\text { Jumlah } \\
\text { petani } \\
\text { (orang) }\end{array}$ & $\begin{array}{c}\text { Persentase } \\
(\%)\end{array}$ \\
\hline 2 & 4 & 20 \\
\hline $3-4$ & 10 & 50 \\
\hline 5 & 6 & 30 \\
\hline Jumlah & 20 & 100 \\
\hline
\end{tabular}

Sumber: Data Primer, 2010

\section{Jarak Perkebunan}

Jarak perkebunan dapat mempengaruhi pengeluaran dalam suatu usahatani. Jarak yang jauh biasanya mempengaruhi terhadap biaya pengangkutan atau transportasi. Walaupun jarak jauh dan memiliki kendaraan atau fasilitas pengangkutan untuk usahatani. Dapat memperkecil biaya yang akan di keluarkan.

Tabel 6. Jumlah dan Persentase Petani Responden Berdasarkan Jarak Perkebunan yang di Usahakan

\begin{tabular}{|c|c|c|}
\hline $\begin{array}{c}\text { Jarak } \\
\text { perkebunan } \\
(\mathrm{km})\end{array}$ & $\begin{array}{c}\text { Jumlah Pe- } \\
\text { tani } \\
\text { (orang) }\end{array}$ & $\begin{array}{c}\text { Persentase } \\
(\%)\end{array}$ \\
\hline $1-3$ & 7 & 35 \\
\hline $4-6$ & 8 & 40 \\
\hline $7-9$ & 5 & 25 \\
\hline Jumlah & 20 & 100 \\
\hline
\end{tabular}

Sumber: Data Primer, 2010

Tabel 6 menunjukan bahwa jarak perkebunan yang terbesar adalah pada kelompok jarak $4-6$ $\mathrm{km}$ atau 40 persen dari jumlah petani responden dan jarak perkebunan yang paling terkecil pada kelompok jarak $7-9 \mathrm{~km}$ atau 25 persen dari jumlah petani responden.

\section{Status pemilikan lahan \\ Keadaan usahatani}

Status lahan yang dimiliki petani menentukan besar kecilnya pendapatan yang akan diterima petani. Dari hasil penelitian menunjukan bahwa lahan usahatani di Desa Tolombukan Kecamatan Pasan umumnya milik sendiri

\section{Luas lahan}

Keadaan lahan dan luas lahan akan mempengaruhi besarnya jumlah produksi dan penggunaan tenaga kerja. Lahan yang di kelola dengan baik akan berbeda hasil produksinya dengan lahan yang tidak di kelola dengan baik. Jumlah responden berdasarkan luas lahan dapat di lihat pada Tabel 7.

Dari Tabel 7 di lihat bahwa luas lahan pada kelompok kurang dari 1 ha itu lebih besar 9 petani atau 45 persen dari jumlah petani responden sedangkan yang terkecil pada kelompok $2,1-4$ ha atau 15 persen dari total petani responden. Hal ini di sebabkan karena pada umumnya petani sampel telah membagikan sebagian lahan yang di usahakan kepada anak - anaknya yang telah berkeluarga.

Tabel 7. Jumlah dan Persentase Petani Responden Berdasarkan Luas lahan

\begin{tabular}{|c|c|c|}
\hline $\begin{array}{c}\text { Luas lahan } \\
\text { (ha) }\end{array}$ & $\begin{array}{c}\text { Jumlah petani } \\
\text { (orang) }\end{array}$ & $\begin{array}{c}\text { Persentase } \\
\text { (\%) }\end{array}$ \\
\hline$\leq 1$ & 9 & 45 \\
\hline $1,1-2$ & 8 & 40 \\
\hline $2,1-4$ & 3 & 15 \\
\hline Jumlah & 20 & 100 \\
\hline
\end{tabular}

Sumber: Data Primer, 2010

\section{Jarak Tanam, Sistem Penanaman dan Jumlah Pohon}

Petani responden di Desa Tolombukan menanam tanaman kelapa dengan jarak tanam $10 \times 10$ meter. Dengan sistem penanaman yang dilakukan bervariasi, tapi umumnya menggunakan sistem persegi atau lurus dengan jumlah pohon 100 hingga 110 pohon per hektar.

\section{Umur tanaman kelapa}

Salah satu faktor penting yang menentukan kemampuan berproduksi dari suatu tanaman. Yaitu usia Tanaman kelapa yang tua, jumlah produksi yang akan di hasilkan berbeda di bandingkan dengan umur tanaman kelapa yang masih muda, di- 
mana kelapa tua produksinya lebih sedikit dari kelapa yang masih muda.

Tabel 8. Umur Tanaman kelapa di Desa Tolombukan Kecamatan Pasan

\begin{tabular}{|c|c|c|}
\hline $\begin{array}{c}\text { Umur Tanaman } \\
\text { (Tahun) }\end{array}$ & $\begin{array}{c}\text { Jumlah Pohon } \\
\text { (Pohon) }\end{array}$ & $\begin{array}{c}\text { Persentase } \\
(\mathbf{\%})\end{array}$ \\
\hline $20-30$ & 777 & 34,50 \\
\hline $31-40$ & 370 & 16,42 \\
\hline $41-50$ & 1105 & 49,06 \\
\hline Jumlah & 2252 & 100 \\
\hline
\end{tabular}

Sumber: Data Primer, 2010

Tabel 8 menunjukan umur tanaman kelapa berkisar dari $20 \mathrm{~s} / \mathrm{d} 50$ tahun dengan jumlah pohon yaitu 2252 pohon atau rata - rata 113 pohon per/hektar, termasuk didalamnya pohon yang produktif dan non produktif.

\section{Produksi}

Produksi adalah proses menggunakan sumberdaya untuk menghasilkan barang - barang atau jasa. Kualitas dan kuantitas produk akan tergantung dari input faktor yang di gunakan akan menurunkan kualitas maupun kuantitas produknya. Usaha peningkatan produksi sekarang ini bukan lagi semata - mata untuk peningkatan kuantitas hasil panen, tetapi di tujukan kepada peningkatan pendapatan petani. Oleh sebab itu petani sekarang lebih berorientasi terhadap harga. Produksi yang meningkat tanpa di dukung oleh tingkat harga yang menguntungkan maka tidak akan memberikan jaminan bagi peningkatan pendapatan usahatani.

Tabel 9. Rata - Rata luas lahan, Jumlah Pohon, Produksi Kelapa Per Tahun

\begin{tabular}{|c|c|c|}
\hline $\begin{array}{c}\text { Luas Lahan } \\
\text { (ha) }\end{array}$ & $\begin{array}{c}\text { Jumlah } \\
\text { Pohon }\end{array}$ & $\begin{array}{c}\text { Produksi } \\
(\mathrm{kg})\end{array}$ \\
\hline 1,59 & 112,35 & 2375,9 \\
\hline
\end{tabular}

Sumber: Data Primer, 2010

Tabel 9 produksi kelapa yang di jadikan objek dalam penelitian ini adalah kopra, dalam satu tahun produksi yaitu empat kali panen berdasarkan hasil penelitian luas lahan rata - rata petani kelapa adalah 1,59 ha dan jumlah pohon 112,35 dengan rata - rata produksi per tahun $2375,9 \mathrm{~kg}$ dan rata rata pohon kelapa yang di budidayakan di lokasi penelitian sudah berbuah (produktif).

Selain mengusahakan tanaman kelapa petani di Desa Tolombukan Kecamatan Pasan juga mengusahakan usahatani lain untuk meningkatkan pendapatan dari usahatani. Dalam satu lahan petani tidak hanya mengusahakan tanaman kelapa tetapi ada usahatani yang lain yaitu cengkeh, yang paling dominan untuk di jadikan sebagai tanaman sela dalam satu lahan.

Rata - rata umur pohon cengkeh 25,1 tahun dan produksi rata - rata tahun 2010 sebesar 323,25 $\mathrm{kg}$ dengan jumlah 113,25 pohon, dan jumlah pohon tidak berbuah (non Produktif) dengan rata rata 30 pohon sehingga produksi menurun itu di akibatkan oleh serangan hama sehingga mendorong para petani untuk mengadakan penyulaman kembali atau penanaman bibit cengkeh yang baru.

\section{Biaya produksi}

Biaya produksi turut menentukan tinggi rendahnya pendapatan di samping besarnya produksi dan harga hasil produksi. Biaya produksi adalah keseluruhan biaya yang di keluarkan selama proses produksi selama satu tahun dalam hal ini produksi kelapa dan tanaman sela.

\section{Biaya Tetap \\ Usahatani kelapa}

Biaya tetap adalah biaya yang tidak tergantung dari besar kecilnya volume produksi. Dalam penelitian ini biaya tetap terdiri atas pajak lahan dan biaya penyusutan. Biaya pajak di Desa Tolombukan Kecamatan Pasan bervariasi tergantung besar luasan lahan yang di miliki oleh petani. Berdasarkan penelitian ini rata -rata pajak per tahun adalah Rp28.225

Untuk biaya penyusutan alat di hitung berdasarkan kepemilikan alat pertanian petani. Dalam penelitian ini peralatan yang akan di hitung penyusutannya adalah parang, cangkul, pencungkil daging dan tempat pengasapan. Rata - rata usia ekonomis $4-8$ tahun kecuali tempat pengasapan rata -rata usia ekonomisnya $7-12$ tahun dan rata-rata penyusutan per tahun sebesar Rp287.986,21. 


\section{Cengkeh (tanaman sela)}

Untuk biaya tetap berupa pajak sudah di hitungkan pada usahatani kelapa karena proses produksi kelapa empat kali per tahun. Sedangkan cengkeh hanya satu kali dalam setahun.

Dalam usahatani cengkih untuk biaya penyusutan peralatan berupa tangga, karung isi, terpal, tali saloy, ayakan, petromax. rata -rata usia ekonomis 2- 5 tahun kecuali tangga hanya sekali pakai dalam 1 kali proses produksi dan rata - rata penyusutan sebesar Rp489.139,16.

\section{Biaya Variabel Pupuk dan Pestisida}

\section{Usahatani kelapa}

Untuk usahatani kelapa umumnya petani responden umumnya tidak menggunakan pupuk karena melihat usia tanaman yang sudah tua dan dari produksi yang mereka peroleh tidak seimbang dengan biaya yang di keluarkan untuk pemupukan dan juga penggunaan pestisida untuk tanaman kelapa petani responden pada umumnya tak meggunakan pestisida karena tanaman kelapa di daerah penelitian bebas oleh serangan hama.

\section{Cengkeh (tanaman sela)}

Untuk tanaman cengkeh ada beberapa petani responden yang sudah menggunakan pupuk dan pestisida adapun jenis pupuk yang di gunakan berupa urea, NPK, Phonska, TSP dan rata - rata biaya penggunaan pupuk per tahun Rp31.750, sedangkan pestisida berupa Desis dan Furadan rata rata biaya pestisida per tahun $\mathrm{Rp} 20.500$.

\section{Biaya Variabel Tenaga Kerja}

\section{Usahatani kelapa}

Sumber penggunaan tenaga kerja ada 2 yaitu: tenaga kerja dalam keluarga dan tenaga kerja luar keluarga (upahan). Biaya tenaga kerja terdiri atas:

a. Pembersihan kebun

Biaya pembersihan kebun untuk usahatani kelapa di Desa Tolombukan Kecamatan Pasan, dari data petani responden yang di peroleh, sebagian besar petani dalam kegiatan pembersihan kebun sudah menggunakan mesin dengan sistem sewa yaitu Rp 100.000 per hari berkisar $7-8$ jam masa pengerjaan. ada juga sebagian kecil petani yang sudah memiliki mesin paras sendiri hanya biaya pengisian bahan bakar (bensin) yang akan di keluarkan oleh petani. Rata - rata biaya pembersihan Rp834.000 per tahun. Proses pembersihan kebun empat kali dalam setahun atau setara dengan proses produksi kopra dalam satu tahun.

b. Pemupukan dan peyemprotan

Untuk tanaman kelapa berdasarkan daerah penelitian para petani responden tidak memakai pupuk dan pestisida.

\section{Usahatani Cengkeh (tanaman sela)}

Penggunaan tenaga kerja untuk pemupukan dan penyemprotan biasa di lakukan oleh tenaga kerja dalam keluarga. ada juga petani yang menggunakan tenaga kerja upahan itu di sebabkan lahan yang di kelolah sangat besar sehingga membutuhkan tenaga kerja lebih dalam pengerjaan. Biasanya biaya pemupukan dan penyemprotan masing masing Rp50.000 per hari rata - rata biaya tenaga kerja pemupukan selama satu tahun Rp13.500 untuk penyemprotan Rp10.000 per tahun.

\section{Biaya Variabel Panen dan Pasca panen Usahatani kelapa}

Biaya panen kelapa meliputi biaya pemanjatan, pengumpulan, pengupasan, pembelahan, pengolahan kopra. Dalam penelitian ini untuk tenaga kerja panen menggunakan tenaga kerja dalam keluarga dan luar keluarga (upahan). Jika tenaga kerja luar keluarga maka untuk biaya pemanjatan di hitung per pohon yaitu Rp2.000 per pohon dengan rata - rata biaya pemanjatan sebesar Rp821.025. Biaya pengumpulan, pengupasan, pembelahan, pengolahan masing - masing di hitung per hari Rp50.000 rata- rata biaya pengumpulan Rp142.225 untuk biaya pengupasan rata - rata per tahun yaitu Rp239.225, rata - rata biaya pembelahan dalam satu tahun adalah Rp209.225 dan biaya rata - rata tenaga kerja dalam satu tahun untuk pengolahan kopra adalah Rp2.543.925.

\section{Usahatani Cengkeh (tanaman sela)}

Dalam penelitian penggunaan tenaga kerja untuk usahatani cengkeh (tanaman sela) menggunakan tenaga kerja dalam keluarga dan luar keluarga (upahan). Biaya panen cengkeh meliputi pemetikan (panen) dan penjemuran. Biasanya biaya tena- 
ga kerja untuk pemetikan di hitung per liter yaitu Rp1.500 biaya makanan di tanggung oleh pemilik cengkeh, ada juga biaya per liter Rp2.500 biaya makanan tidak di tanggung oleh pemilik cengkeh. Tetapi sebagian besar tenaga kerja menerima biaya penyewaan Rp1.500 per liter hal ini di sebabkan karena jarak perkebunan yang begitu jauh sehingga para tenaga kerja sering menetap di kebun selama seminggu. Dan untuk penjemuran sebagian besar tenaga kerjanya hanya berasal dari dalam keluarga dan tidak mengeluarkan biaya tenaga kerja. Dan rata - rata biaya tenaga kerja pemetikan (panen) sebesar Rp2.402.750. Biaya bahan ini merupakan faktor pendukung dalam usahatani cengkeh (tanam sela) yang terdiri biaya makanan (konsumsi) untuk tenaga kerja, biaya minyak tanah untuk lampu penerangan (petromax), biaya lain lain. Untuk biaya makanan (konsumsi) rata - rata per tahun sebesar Rp542.500 dan untuk biaya minyak tanah rata - rata dalam satu tahun (satu kali panen) Rp27.750 dan biaya lain berupa biaya rokok untuk tenaga kerja panen dengan biaya rata rata dalam satu kali panen Rp268.000.

\section{Biaya Variabel Pengangkutan}

\section{Usahatani kelapa}

Biaya pengangkutan hasil dari kebun bervariasi sesuai jarak dan medan yang akan di tempuh. Biasanya biayanya bervariasi ada yang per karung Rp 50.000. dengan rata - rata per karung $80-100$ $\mathrm{kg}$. ada juga petani yang membayar biaya pengangkutan $10 \%$ dari harga keseluruhan hasil penjualan kopra dan ada juga petani responden yang memiliki kendaraan sendiri itu tidak mengeluarkan biaya pengangkutan. rata - rata biaya pengangkutan dalam satu tahun sebesar Rp563.565.

\section{Usahatani Cengkeh (tanaman sela)}

Untuk pengangkutan cengkeh berdasarkan penelitian di Desa Tolombukan Kecamatan Pasan biaya pengangkutan yaitu per karung Rp100.000 dengan berat rata - rata $60-65 \mathrm{~kg}$ cengkeh kering. Sebagian besar petani mengeluarkan cengkehnya dari kebun dalam keadaan kering mengingat biaya pengangkutan yang besar. Dengan rata rata biaya pengangkutan dalam satu kali panen sebesar Rp297.000.

Tabel 10. Menunjukan bahwa usahatani kelapa jumlah biaya rata - rata sebesar 9,23 persen,

Tabel 10. Rata - rata Biaya Produksi Usahatani Kelapa dan Cengkeh (tanaman sela) dalam Satu Tahun Produksi

\begin{tabular}{|c|c|c|c|c|}
\hline \multirow{2}{*}{$\begin{array}{c}\text { Biaya } \\
\text { produksi }\end{array}$} & \multicolumn{4}{|c|}{ Usahatani } \\
\cline { 2 - 5 } & \multicolumn{2}{|c|}{ Kelapa } & \multicolumn{2}{c|}{ Cengkeh } \\
\cline { 2 - 5 } & $\mathrm{Rp}$ & $\%$ & - & Rp \\
\hline A. Biaya Tetap (Rp) & 28.225 & 0,82 & $489.139,16$ & 11,95 \\
\hline - Biaya Pajak & $287.986,21$ & 8,41 & $489.139,16$ & 11,95 \\
\hline - Penyusutan Alat & $316.211,21$ & 9,23 & 52.250 & 1,30 \\
\hline Jumlah Biaya Tetap & - & - & 3.264 .500 & 79,50 \\
\hline B. Biaya Variabel (Rp) & 2.543 .925 & 74,30 & 297.000 & 7,23 \\
\hline - Saprodi & 563565 & 16,46 & 3.613 .750 & 88,05 \\
\hline - Tenaga kerja & 3.107 .490 & 90,76 & 3.70 \\
\hline - Transportasi & $3.423 .701,22$ & 100,00 & $4.104 .554,16$ & 100,00 \\
\hline Jumlah Biaya Variabel
\end{tabular}

Sumber: Data Primer, 2010 
sedangkan untuk usahatani cengkeh (tanaman sela) sebesar 11,95 persen ini menunjukan bahwa penggunaan peralatan usahatani masih lebih banyak pada usahatani cengkeh (tanaman sela). Untuk biaya variabel usahatani kelapa sebesar 90,76 persen dan usaha tani selain kelapa (cengkeh) 88,05 dapat dilihat untuk biaya transportasi usahatani kelapa lebih besar dari pada usahatani cengkeh (tanaman sela). karena kelapa selama satu tahun empat kali berproduksi (kopra) sedangkan cengkeh hanya satu tahun sekali berproduksi. Akan tetapi biaya tenaga kerja masih lebih besar usahatani cengkeh (tanaman sela) dari pada usahatani kelapa.

\section{Harga}

\section{Penerimaan dan Pendapatan}

Harga merupakan persetujuan antara pembeli dan penjual dalam menilai suatu produk tertentu. Harga berdasarkan hasil penelitian harga kopra (kopra hari - hari) yaitu Rp3.500 per kilogram. Untuk harga tanaman sela di daerah penelitian dalam hal ini cengkeh adalah Rp49.000 per kilogram.

\section{Penerimaan dan pendapatan}

Penerimaan adalah perkalian antara produksi yang diperoleh dengan harga jual produk tersebut. Pendapatan usahatani adalah selisih antara penerimaan dan semua biaya yang dikeluarkan dalam suatu usahatani. Pendapatan dalam penelitian ini adalah pendapatan petani kelapa dan pendapatan usahatani cengkeh (tanaman sela) di Desa Tolombukan Kecamatan Pasan.

Tabel 16. Rata - rata Penerimaan dan Pendapatan Petani per Tahun di Desa Tolombukan Kecamatan Pasan

\begin{tabular}{|l|c|c|c|}
\hline $\begin{array}{l}\text { Jenis Usa- } \\
\text { hatani }\end{array}$ & $\begin{array}{c}\text { Total } \\
\text { Penerimaan } \\
(\mathrm{Rp})\end{array}$ & $\begin{array}{c}\text { Total } \\
\text { Biaya Pro- } \\
\text { duksi (Rp) }\end{array}$ & $\begin{array}{c}\text { Pendapatan } \\
(\mathrm{Rp})\end{array}$ \\
\hline $\begin{array}{l}\text { Usahatani } \\
\text { Kelapa }\end{array}$ & 8.315 .650 & 3.423 .701 & 4.891 .948 \\
\hline $\begin{array}{l}\text { Usahatani } \\
\text { lain } \\
\text { (cengkeh) }\end{array}$ & 15.839 .250 & 4.104 .554 & 11.734 .695 \\
\hline $\begin{array}{l}\text { Total } \\
\text { Pendapatan }\end{array}$ & 16.626 .644 & & \\
\hline
\end{tabular}

Sumber: Data Primer, 2010
Tabel 16 menunjukan dari hasil penelitian membuktikan bahwa usahatani kelapa dengan adanya tanaman sela (cengkeh) dapat memberi peningkatan dalam hal ini total pendapatan petani sebesar Rp16.626.644 per tahun.

\section{Pemasaran}

Untuk usahatani kelapa keseluruhan petani hanya menjual kepada pedagang pengumpul yang berada di desa Tolombukan Kecamatan Pasan sedangkan selain usahatani kelapa (cengkeh) biasanya pedagang pengumpul yang menjemput hasil usahataninya ke rumah dengan mobil dengan harga Rp49.000 sehingga biaya transportasi pemasaran tidak perlu di keluarkan oleh petani responden.

\section{KESIMPULAN DAN SARAN}

\section{Kesimpulan}

Berdasarkan hasil penelitian menunjukkan bahwa pengelolaan usahatani kelapa di Desa Tolombukan Kecamatan Pasan dapat di simpulkan bahwa:

a. Pemilikan lahan usahatani di Desa Tolombukan Kecamatan Pasan milik sendiri

b. Lokasi perkebunan kelapa dari masing - masing petani tersebar (bukan terkumpul). Jarak tanam untuk usahatani kelapa yaitu $10 \times 10 \mathrm{~m}$.

c. Pohon kelapa di Desa Tolombukan Kecamatan Pasan Rata - rata berumur tua.

d. Keseluruhan petani menjual hasil usahataninya kepada pedagang pengumpul.

e. Biaya terbesar pada usahatani kelapa adalah biaya tenaga kerja.

f. Total pendapatan usahatani kelapa di Desa Tolombukan Kecamatan Pasan sebesar Rp16.626.644. Sebesar 70,57 persen merupakan kontribusi dari tanaman sela (cengkih).

\section{Saran}

Berdasarkan kesimpulan yang telah dikemukakan maka dapat di sarankan sebagai berikut:

a. Perlu adanya peran dari pemerintah atau lembaga yang berkaitan dengan pemasaran untuk menjaga kestabilan harga produk kelapa dan usahatani selain kelapa (cengkeh), 
sehingga petani bisa mendapatkan harga yang layak.

b. Petani harus dapat menekan biaya panen, karena dengan meminimalisir biaya panen diharapkan dapat meningkatkan pendapatan bersih petani

\section{DAFTAR PUSTAKA}

Adiwilaga, 1982. Ilmu Usahatani. Penerbit Alumni Bandung.

Anonymous, 1980. Pedoman Pengelolaan Usahatani. Direktorat Jenderal Pertanian Tanaman Pangan dan Holtikultura, Departemen Pertanian Jakarta.

Anonymous. 2008. Maksimalisasi tanaman kelapa di Indonesia.

http://.wordpress.com=maksimalisasi-kelapapart-1/

Bishop, C. E. and W.D. Toussaint, 1979. Pengantar Analisis Ekonomi Pertanian. Terjemahan Wisnuadji dkk. Yogyakarta

Darwis, SN, 1996. Pedoman Pengelolaan Usahatani. Direktorat Jenderal Pertanian Tanaman Pangan dan Holtikultura. Departemen Pertanian, Jakarta.

Djojodipuro, 1991. Teori Harga, Lembaga Penerbit Fekon UI Press Jakarta.
Hernanto, F. 1993. Ilmu Usahatani, Penebar Swadaya, Jakarta

Kartasapoetra. 1991. Hukum Tanah. Rineka Cipta. Jakarta

Kotler, P. 1986. Manajemen Pemasaran. Erlangga. Jakarta

Mahmud Z., 1998. Tanaman Sela. Jurnal Penelitian dan Pengembangan Pertanian. Departemen Pertanian. Jakarta

Mubyarto, 1991. Pengantar Ekonomi Pertanian. LP3ES. Jakarta.

Mosher,A.P. 1965. Menggerakan dan Pembangunan Pertanian. CV Yasangun Jakarta.

Ratag, J, 1982. Dasar - Dasar Pengelolaan Usahatani. Fakultas Pertanian Universitas Sam Ratulangi. Manado.

Simanjuntak, P.J. 1983. Produktifitas Kerja Pengertian dan Ruang Lingkupnya.LP3ES. Jakarta.

Soekartawi, 1995. Analisis Usahatani. Universitas Indonesia. Jakarta.

Soeharjo, A. dan Patog, D. 1973. Sendi -Sendi Pokok Ilmu Usahatani. Jurusan Sosial Ekonomi Fakultas Pertanian IPB. Bogor

Sukamto, 2001. Upaya meningkatkan produksi kelapa. PT. Penebar Swadaya. Jakarta 